\title{
Association of conception rate with pattern and level of somatic cell count elevation relative to time of insemination in dairy cows
}

\author{
Y. Lavon, ${ }^{\star}$ E. Ezra, $†$ G. Leitner, $¥$ and D. Wolfenson ${ }^{* 1}$ \\ *Department of Animal Sciences, Faculty of Agriculture, Food and Environment, the Hebrew University, Rehovot 76100, Israel \\ †Israel Cattle Breeders Association, Caesarea 38900, Israel \\ $\ddagger$ Mastitis Laboratory, The Veterinary Institute, Bet Dagan 50250, Israel
}

\section{ABSTRACT}

The aim was to evaluate the effects of mastitis, determined by the pattern and level of somatic cell count (SCC) around first artificial insemination (AI), on conception rate (CR). Data from 287,192 first AI and milk records covering a 7 -yr period were obtained from the Israeli Herd Book. Analyses examined the association of probability of conception with SCC elevation relative to timing of $\mathrm{AI}$, using generalized linear mixed models. A SCC threshold of 150,000 cells/mL of milk was set to distinguish between uninfected cows and cows with mastitis. Accordingly, cows with high SCC before and low SCC after AI were designated cured, those with low SCC before and high SCC after AI were designated newly infected, and cows with high SCC before and after AI were designated chronic (likely subclinical) mastitic cows. Compared with uninfected cows, the cured, newly infected, and chronic subgroups showed reduced $\mathrm{CR}(39.4 \pm 0.1,36.6 \pm 0.2,32.9 \pm 0.3$, and $31.5 \pm 0.2$, respectively). In the chronic, subclinical group, probability of conception was lowered by $14.5 \%$ in the mild and moderately elevated SCC subgroups and by $20.5 \%$ in cows with high SCC elevation compared with the uninfected group (CR of 29.7 vs. $39.4 \%$, respectively). A single high elevation of SCC $\left(>10^{6}\right.$ cells $/ \mathrm{mL}$ on only 1 milk test day) lowered the probability of conception by $23.6 \%$ when it occurred during the $10 \mathrm{~d}$ immediately before AI, but not when it occurred earlier. For $30 \mathrm{~d}$ after AI, probability of conception was lowered by about $23 \%$, as reflected in a CR of about $27 \%$ compared with the uninfected group. Probability of conception was lowered in cows with uterine and foot health problems (33.9\%), in multiparous cows (34.1\%), and in cows in the summer $(29.1 \%)$, but no interactions with mastitis were detected. Results indicate that SCC elevation around AI, typical for subclinical mastitis, was associated with a significant reduction in probability of conception, and that even mild SCC elevation reduced

Received February 21, 2011.

Accepted May 24, 2011.

${ }^{1}$ Corresponding author: wolf@agri.huji.ac.il
CR. Severe elevation of SCC before AI, typical for clinical intramammary infection, reduced the probability of conception.

Key words: mastitis, somatic cell count, conception, dairy cow

\section{INTRODUCTION}

Mastitis, in its clinical or subclinical forms, is a major disease that is common in dairy cattle, resulting in loss of milk production, an increase in discarded milk, increased use of veterinary services and drugs, higher culling rates, and occurrence of other diseases (Halasa et al., 2007). The economic loss associated with reproduction failure, generally neglected in the past, has gained attention in the last decade.

Somatic cell count in milk is an indicator of the activity of the cellular immune defense system. Milk from healthy udders exhibits a physiological basal cell count that varies between 18,000 and 200,000 cells/mL, with a geometric mean of 68,000 cells $/ \mathrm{mL}$ of milk. Cows with subclinical mastitis can have an SCC of up to a few million cells per milliliter. The geometric means of the most common gram-positive bacteria-induced subclinical IMI range from 155,000 to $1,129,000$ cells/ $\mathrm{mL}$ and vary with the bacterial species involved (Djabri et al., 2002; Schukken et al., 2003). Different species of CNS are the most frequently isolated bacteria from udder infections in dairy cows, prevailing in a range of 5 to 50\% (Taponen et al., 2006; Parker et al., 2007). It has been shown that CNS can survive in the udder for months, or even throughout the lactation period (Aarestrup et al., 1999). In subclinical mastitis, the immunological response (as determined by SCC) is moderate compared with the clinical response to bacteria such as Staphylococcus aureus and Escherichia coli (Smith, 1995); the latter is associated with a transient increase in SCC on the order of several million cells per milliliter.

Cows that develop clinical mastitis in early lactation were less likely to conceive (Santos et al., 2004). A study based on a large data set (Loeffler et al., 1999) found a small effect of clinical mastitis on conception when 
it occurred before AI, and a much more pronounced effect when it occurred after AI. Accordingly, Hertl et al. (2010) found that clinical mastitis occurring from $14 \mathrm{~d}$ before to $28 \mathrm{~d}$ after AI decreased conception rates (CR). Those authors suggested that the reduction in pregnancy rate could be related to the release of inflammatory mediators such as $\mathrm{PGF}_{2 \alpha}$, which can alter the inter-estrus interval by causing premature luteolysis.

The effect of subclinical IMI on fertility is controversial. Reduced reproductive efficiency, and increased days to first AI, open days, and services per conception have been reported (Schrick et al., 2001). In contrast, a comprehensive data analysis (Miller et al., 2001) showed only a small and unclear effect of elevated SCC before AI on nonreturn rate in Holstein cows and no influence in Jersey cows. We recently found that low circulating estradiol in $30 \%$ of subclinical mastitic cows was associated with a low and delayed LH surge, leading to delayed ovulation (Lavon et al., 2010). In cows, extension of the normal estrus-to-ovulation interval from about 30 to $60 \mathrm{~h}$ may reduce the probability of successful fertilization because of the short fertile life of spermatozoa in the female tract and of the oocytes after ovulation (Hunter, 1994). This phenomenon was related to a reduction in steroid production and low mRNA expression of steroidogenic genes and LH receptor in the preovulatory follicle of subclinical mastitic cows (Lavon et al., 2011). Collectively, the above shows a close relationship between patterns of SCC elevation and type of IMI (clinical or subclinical) and its possible association with reduced fertility. The aim was to evaluate the effects of mastitis on CR, as determined by pattern and level of SCC in routine monthly milk tests collected before and after first AI.

\section{MATERIALS AND METHODS}

\section{Study Design}

Data were collected from 2002 to 2008 from the milkrecording program of the Israeli Cattle Breeders' Association Center. Records from 287,192 AI of 151,481 primiparous and multiparous Holstein cows, from 222 commercial dairy farms located throughout the country were collected. Routine AI was performed following detection of estrus, and pregnancy was confirmed by rectal palpation 40 to $60 \mathrm{~d}$ after AI. Cows that manifested estrus before being checked for pregnancy and those that were not diagnosed as pregnant were recorded as nonpregnant. Composite milk samples were obtained by certified technicians during monthly visits to the farms. Samples were preserved by addition of potassium dichromate and analyzed in a Fossomatic 360 (Foss Electric, Hillerød, Denmark) for SCC. The rel- evant data included lactation number, date of calving, SCC, date of AI, and health status not related to IMI. Although the latter was subject to variation among veterinarians working on the farms included in this study (in terms of diagnostics of disease severity and corresponding treatments), uterine and foot diseases were included in the analyses, in particular to examine their interaction with IMI. Postpartum uterine diseases included retained fetal membranes (for more than $24 \mathrm{~h}$ after calving); metritis (enlarged nonpregnant uterus with inflammation and purulent vaginal discharge), or a pyometra (enlarged nonpregnant uterus with purulent content at least 30 to $40 \mathrm{~d}$ postpartum). Foot diseases included lameness that required treatment, panaritium, and laminitis. Information on these diseases was collected from farmers' reports based on a veterinarian's diagnosis, and were designated diseases other than IMI. The mean length of the voluntary waiting period from calving to first AI was $93 \pm 17$ (SD) d. Somatic cell count was used as an indication of IMI. An SCC threshold of 150,000 cells/mL milk was set to distinguish between uninfected and IMI cows. This threshold was based on a meta-analysis of 21 published studies conducted in different countries, showing that cows infected with CNS have a mean of 155,000 cells $/ \mathrm{mL}$ (Djabri et al., 2002). Therefore, reducing the threshold to 100,000 cells $/ \mathrm{mL}$ might place cows that are free of infection into the subclinical group, whereas increasing the threshold to 200,000 cells/mL might place cows infected with CNS into the uninfected group. The variability in SCC thresholds set by several studies over the years has been reviewed by Schukken et al. (2003). In the current study, cows were divided into 4 groups according to SCC pattern [stable low $(<150,000$ cells/ $\mathrm{mL})$, stable high $(>150,000$ cells $/ \mathrm{mL})$, ascending or descending], and SCC level on 3 monthly milk test days around first AI: 2 before AI and 1 after AI. The collection of SCC information was limited to only 1 monthly milk test day post-AI to avoid confounding information related to outcome of first AI. Nevertheless, an additional milk test-day sample after AI was included in the third model analysis (as described below).

Group 1 included uninfected cows $(\mathrm{n}=178,512 \mathrm{AI})$, which had SCC $<150,000$ cells $/ \mathrm{mL}$ on all 3 monthly test days. Cows in group $2(\mathrm{n}=42,308 \mathrm{AI})$ had SCC $>150,000$ cells $/ \mathrm{mL}$ on at least 1 of the 2 monthly test days before AI and SCC $<150,000$ cells $/ \mathrm{mL}$ after AI; this group was designated cured of infection. Cows in group $3(\mathrm{n}=19,998 \mathrm{AI})$ had $\mathrm{SCC}<150,000$ cells $/ \mathrm{mL}$ on the 2 monthly test days before first AI and SCC $>150,000$ cells $/ \mathrm{mL}$ after AI; this group was designated new infection. Groups 2 and 3 most likely included short-term clinical IMI events, presented as a single elevation in $\mathrm{SCC}>150,000$ cells $/ \mathrm{mL}$ on a single monthly 
milk test day. Cows in group $4(\mathrm{n}=46,374 \mathrm{AI})$ had SCC $>150,000$ cells $/ \mathrm{mL}$ on at least 1 of the 2 monthly test days before first AI as well as on the test day after AI. Thus, in at least 2 of 3 milk test day samples, SCC was $>150,000$ cells $/ \mathrm{mL}$; accordingly, this group was designated chronic infection and most likely represented subclinical mastitis, due to the long-term nature of this disease. A total of 3,190 AI obtained $1 \mathrm{~d}$ before to $1 \mathrm{~d}$ after AI were excluded from the analyses to eliminate possible estrous effects on SCC (not related to IMI), which may be associated with an increase in SCC.

\section{Data Analyses}

A multivariate model was designed with a logistic model statement using the GLIMMIX procedure of SAS (2002-2008, SAS Institute Inc., Cary, NC), with AI outcome as the dependent variable. First AI CR was calculated as number of pregnancies divided by number of AI. In the first analysis, the entire data set $(\mathrm{n}=$ 287,192 AI) was analyzed, with the general form

$$
\begin{gathered}
\text { CR }=\text { SCC groups }+ \text { Herd-Year }+ \text { Disease } \\
+ \text { Calving month }+ \text { Season }+ \text { Parity }+ \text { Year }+ \text { VWP } \\
+ \text { SCC groups } \times \text { Parity }+ \text { SCC groups } \times \text { Disease }+ \\
\text { SCC groups } \times \text { Season }+ \text { Year } \times \text { Parity }+ \text { VWP } \\
\times \text { Parity }+ \text { Season } \times \text { Parity }+ \text { Disease } \times \text { Parity } \\
+ \text { Disease } \times \text { Season }+ \text { error },
\end{gathered}
$$

where $\mathrm{CR}=\ln P /(1-P)$ and $P=$ probability of pregnancy; SCC groups $=$ the 4 experimental groups; Herd-Year $=1,385$ commercial dairy herds within year of insemination (random effect); Disease $=$ health status not related to IMI, as described above; Calving month $=6$ categories of calving months $(1=$ January-February, $2=$ March-April, ... $6=$ NovemberDecember); Season of AI = summer and fall (July to October), winter and spring (November to June); Parity $=$ primiparous or multiparous cows; Year $=7$ categories of year of calving (2002 to 2008); VWP = voluntary waiting period (a continuous variable); and interactions. All variables were considered fixed effects, except Herd-Year, which was considered a random effect. Milk yield and all of the third-degree interactions tested were found not significant and were excluded from the final model. Probability of conception for a level of a specific variable included in the model was based on least squares means values.

The second analysis $(\mathrm{n}=224,886 \mathrm{AI})$ examined the effect of SCC level on CR in the chronic group. Included in the analysis were cows (designated subclinical
SCC groups) from the uninfected group (group 1) serving as controls $(\mathrm{n}=178,512 \mathrm{AI})$ and from the chronic (subclinical) group $(\mathrm{n}=46,374 \mathrm{AI}$; group 4$)$, which were divided into 3 subgroups: (1) mild $\mathrm{SCC}=$ cows with SCC between 150,000 and 450,000 cells/mL in at least 1 of 2 milk tests before AI and in the milk test after $\mathrm{AI}$, and $\mathrm{SCC}<450,000$ cells $/ \mathrm{mL}$ in the second milk test before AI ( $\mathrm{n}=17,414 \mathrm{AI})$; (2) moderate SCC $=$ cows with SCC between 450,000 and $10^{6}$ cells $/ \mathrm{mL}$ in at least 1 of 2 milk tests before AI and in the milk test after $\mathrm{AI}$, and $\mathrm{SCC}<10^{6}$ cells $/ \mathrm{mL}$ in the second milk test before $\mathrm{AI}(\mathrm{n}=12,014 \mathrm{AI})$; (3) high $\mathrm{SCC}=$ cows with SCC above $10^{6}$ cells $/ \mathrm{mL}$ in at least 1 of 2 milk tests before $\mathrm{AI}$ and in the milk test after $\mathrm{AI}$, and $\mathrm{SCC}$ $>150,000$ cells $/ \mathrm{mL}$ in the second milk test before AI $(\mathrm{n}=16,946 \mathrm{AI})$. Conception rate was analyzed by the effects described in the above model [1], except that the SCC group variable was designated subclinical SCC group.

The third analysis included a total of 194,745 AI of uninfected cows ( $\mathrm{n}=178,512$ AI; group 1$)$ and subpopulations of cows from the cured (group 2) and new infection (group 3) groups that exhibited a single elevation in SCC at specific periods of time before or after AI $(\mathrm{n}=16,233 \mathrm{AI})$. Included in the analysis were elevated SCC events whose SCC values on the milk test days preceding and subsequent to it were $<150,000$ cells/ $\mathrm{mL}$ (most likely associated with a short-term clinical IMI event). Accordingly, the additional milk test-day samples included in the third model analysis only served to confirm that a single elevation in SCC on the milk test day after AI was followed by a low, uninfected SCC level. Thus, a single elevated SCC sample in this analysis was recorded in the milk test-day samples taken closer (before or after) to AI. Cows were divided into 3 subgroups: mild $=$ SCC elevated between 150,000 and 450,000 cells $/ \mathrm{mL}$; moderate $=$ SCC elevated between 450,000 and $10^{6}$ cells $/ \mathrm{mL}$; and high $=$ SCC elevated above $10^{6}$ cells $/ \mathrm{mL}$. Each of the above 3 subgroups was further divided into 6 subgroups of $10 \mathrm{~d}$ each according to the time of SCC elevation before AI: -30 to -21 , -20 to $-11,-10$ to $-1 \mathrm{~d}$, and after AI: +1 to $+10,+11$ to +20 and +21 to +30 ; thus, 18 subgroups plus the uninfected group were formed, and designated clinical SCC groups (as presented later). Conception rate was analyzed by the same model [1] as above, except that the SCC group variable was defined as clinical SCC group.

\section{RESULTS}

\section{First Analysis: Overall Data Set}

Analysis of the overall data set indicated that an elevation in SCC, regardless of level or time of eleva- 
Table 1. The generalized mixed model used to estimate the effect of different types of mastitis, determined by pattern and level of SCC elevation around first AI and other variables, on probability of conception following $287,192 \mathrm{AI}$ in 151,481 cows from 222 commercial dairy farms in 2002 to $2008^{1}$

\begin{tabular}{|c|c|c|c|c|}
\hline Variable & Level & $\mathrm{n}$ & LSM diff. $^{2}$ & $\mathrm{SE}$ \\
\hline SCC group ${ }^{3}$ & $\begin{array}{l}\text { Uninfected } \\
\text { Cured } \\
\text { New } \\
\text { Chronic }\end{array}$ & $\begin{array}{r}178,512 \\
42,308 \\
19,998 \\
46,374\end{array}$ & $\begin{array}{l}\text { Ref. } \\
-0.014^{* 4} \\
-0.053^{*} \\
-0.059^{*}\end{array}$ & $\begin{array}{l}-\overline{-} \\
0.014 \\
0.021 \\
0.015\end{array}$ \\
\hline Health problems & $\begin{array}{l}\text { No } \\
\text { Yes }\end{array}$ & $\begin{array}{r}211,045 \\
76,147\end{array}$ & $\begin{array}{l}\text { Ref. } \\
-0.044^{*}\end{array}$ & $\overline{0.014}$ \\
\hline Parity & $\begin{array}{l}1 \\
2+\end{array}$ & $\begin{array}{l}106,789 \\
180,403\end{array}$ & $\begin{array}{c}\text { Ref. } \\
-0.11^{*}\end{array}$ & $\overline{0.011}$ \\
\hline Season & $\begin{array}{l}\text { Winter } \\
\text { Summer }\end{array}$ & $\begin{array}{r}205,355 \\
81,837\end{array}$ & $\begin{array}{c}\text { Ref. } \\
-0.08^{*}\end{array}$ & $\overline{0.015}$ \\
\hline Year & $\begin{array}{l}2002 \\
2003 \\
2004 \\
2005 \\
2006 \\
2007 \\
2008\end{array}$ & $\begin{array}{l}40,953 \\
40,256 \\
41,740 \\
40,005 \\
39,149 \\
42,387 \\
42,702\end{array}$ & $\begin{array}{c}\text { Ref. } \\
0.004 \\
-0.019 \\
-0.032^{*} \\
-0.041^{*} \\
-0.046^{*} \\
-0.050^{*}\end{array}$ & $\begin{array}{l}-\overline{ } \\
0.022 \\
0.022 \\
0.022 \\
0.023 \\
0.023 \\
0.023\end{array}$ \\
\hline
\end{tabular}

${ }^{1}$ Number of AI, variable least squares means difference (diff), SE, and $P$-values are presented for each variable. ${ }^{2}$ The values in the LSM column are deviations from the Reference levels. Reference levels of SCC, health problems, parity, season, and year are 0.0 , corresponding to conception rates of $0.365,0.356,0.389,0.374$, and 0.360 , respectively.

${ }^{3}$ Uninfected cows had SCC $<150,000$ cells $/ \mathrm{mL}$ before and after AI; cured cows had SCC $>150,000$ cells $/ \mathrm{mL}$ before AI and SCC $<150,000$ cells/mL after AI; new infection cows had SCC $<150,000$ cells/mL before AI and SCC $>150,000$ cells/mL afterward; chronic infection cows had SCC $>150,000$ cells $/ \mathrm{mL}$ before and after AI.

${ }^{4}$ Cured group differed from new and chronic groups $(P<0.05)$.

*A level within a variable was considered significant at $P<0.05$ if confidence range of the specific level did not overlap with the corresponding range of the reference.

tion in relation to $\mathrm{AI}$, decreased the probability of conception relative to that of uninfected cows (Table 1). Analysis showed that all main effects (including VWP and its interaction with parity) were significant $(P<$ 0.001 ), and that none of the 2-way interactions with SCC experimental groups was statistically significant. Cows in the cured group had a 3.8\% (0.014/0.365; LSM difference between cured and uninfected groups divided by LSM of the uninfected group) lower probability of conception $(P<0.05)$ than uninfected controls and a higher probability than new and chronic infection groups $(P<0.05)$. Probability of conception in the new infection group was $14.5 \%$ lower than in the uninfected group $(P<0.05$; Table 1$)$. Additional calculations with this subgroup indicated that most $(85 \%)$ of the cows exhibited elevated SCC after AI in the range of 150,000 to $10^{6}$ cells $/ \mathrm{mL}$, whereas only $15 \%$ exhibited SCC above $10^{6}$ cells $/ \mathrm{mL}$. The largest reduction was recorded for chronic, subclinical mastitis, with a probability of conception that was $16.2 \%(0.059 / 0.365)$ lower $(P<$ 0.05 ; Table 1) than in the uninfected group. The actual mean CR for the 4 experimental groups are presented in Figure 1. For example, mean CR of uninfected cows and cows with chronic mastitis were $39.4 \pm 0.1$ and $31.5 \pm 0.2 \%$, respectively $(P<0.05)$.

\section{Second Analysis: Association of SCC Level with Probability of Conception in Chronic, Subclinical Cows}

The second analysis [on uninfected cows (group 1) and chronic (subclinical) mastitic cows (group 4)] showed that this effect varied with SCC level (Table 2 ). Compared with uninfected controls, the probability of conception decreased by 14.1 to $14.5 \%(P<0.05)$ in subgroups with mildly and moderately elevated SCC; however, the high SCC elevation subgroup of subclinical cows exhibited the largest decline in probability of conception (20.5\%, Table 2; $P<0.05)$. Figure 2 depicts the actual mean $\mathrm{CR}$ values of the mildly, moderately, and highly elevated SCC subgroups of chronic, subclinical cows relative to uninfected controls. For example, 


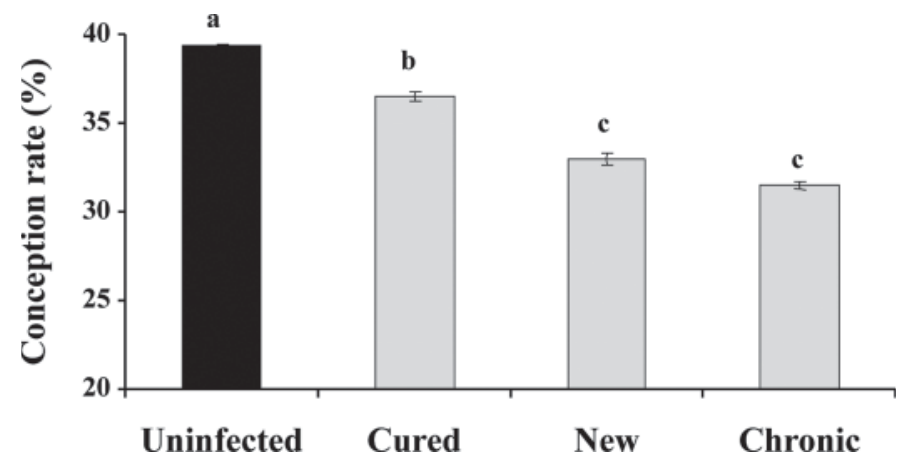

Figure 1. Effect of mastitis type on conception rates. Number of AI: uninfected group $(\mathrm{n}=178,512)$, cured group $(\mathrm{n}=42,308)$, new infection group $(\mathrm{n}=19,998)$, chronic group $(\mathrm{n}=46,374)$. Data are presented as mean \pm SEM. Different letters denote significant differences at $P<0.05$

the mean CR of uninfected cows and the high SCC elevation subgroup were $39.4 \pm 0.1$ and $29.7 \pm 0.35 \%$, respectively $(P<0.05)$.

\section{Third Analysis: Effect of SCC Elevation in a Single Milk Test Before or After Al on Probability of Conception}

A single elevation of SCC in a monthly milk test-day sample recorded during the $30 \mathrm{~d}$ before or after AI is most likely associated with a short-term clinical IMI event. Consequently, the effect of high SCC elevation $\left(>10^{6}\right.$ cells $\left./ \mathrm{mL}\right)$ corresponded more closely to the exact timing of the clinical event than the mild or moderate SCC elevations, which likely corresponded to the later,

Table 2. The generalized mixed model used to estimate the effect of different types of chronic (subclinical) mastitis, determined by level of SCC elevation before and after first AI (for further details, see text), on probability of conception following 224,886 AI at 222 commercial dairy farms in 2002 to $2008^{1}$

\begin{tabular}{llrll}
\hline Variable $^{2}$ & $\begin{array}{l}\text { Level } \\
\text { (cells/mL) }\end{array}$ & $\mathrm{n}$ & \multicolumn{1}{c}{$\begin{array}{l}\text { LSM } \\
\text { diff. }^{3}\end{array}$} & SE \\
\hline SCC & & & & \\
Uninfected & $<150,000$ & 178,512 & \multicolumn{1}{c}{ Ref. } & - \\
Mild & $150,000-450,000$ & 17,414 & $-0.052^{*}$ & 0.021 \\
Moderate & $450,000-10^{6}$ & 12,014 & $-0.053^{*}$ & 0.027 \\
High & $>10^{6}$ & 16,946 & $-0.075^{*}$ & 0.025
\end{tabular}

${ }^{1}$ Number of AI, variable least squares means difference, SE, and $P$-values are presented for each variable.

${ }^{2}$ Health problems other than mastitis, parity, season, and year of data collection significantly affected probability of conception in this data subset as in the full data set (Table 1) and are not presented here.

${ }^{3}$ The values in the LSM column are deviations from the Reference levels; reference level of the variable is 0.0 , corresponding to conception rate of 0.365 .

*A level within a variable was considered significant at $P<0.05$ if confidence range of the specific level did not overlap with the corresponding range of the reference. post-event period (Table 3). A high elevation in SCC decreased the probability of conception by $23.6 \%$ when it occurred during the $10 \mathrm{~d}$ before AI $(P<0.05)$, but had no effect if it occurred earlier, during $d-11$ to -20 or -21 to -30 before AI (Table 3 ). High elevation in SCC after AI was associated with a reduction in the probability of conception during the entire period $(-22.2$ to $-23.6 \% ; P<0.05$; Table 3$)$. The actual CR decreased between $26.1 \pm 1.5$ and $28.8 \pm 1.7 \%$ when SCC elevation occurred during $\mathrm{d}-10$ before to +30 after AI, compared with $39.4 \pm 0.1 \%$ in the uninfected group $(P<0.05$; Figure 3$)$.

\section{Effects of Variables Other than IMI on Conception}

Health problems associated with postpartum uterine diseases or foot diseases decreased the probability of conception $(P<0.05$; Table 1$)$. Multiparous cows had a $26.2 \%$ lower probability of conception than did primiparous cows $(P<0.05$; Table 1$)$. Probability of conception of cows during the summer and autumn was 19.3\% less than that when AI was conducted during the winter and spring $(P<0.05$; Table 1$)$. A $5 \%$ range in probability of conception was noted during the $7 \mathrm{yr}$ of the study (Table 1). Interaction of the above variables with mastitis was not detected. Very similar effects of health status, parity, season, and year of study were documented for the above variables in the second and third analyses, and therefore, data are not shown in Tables 2 or 3 .

\section{DISCUSSION}

The most important finding was the approximately $14.3 \%$ decrease in probability of conception among the

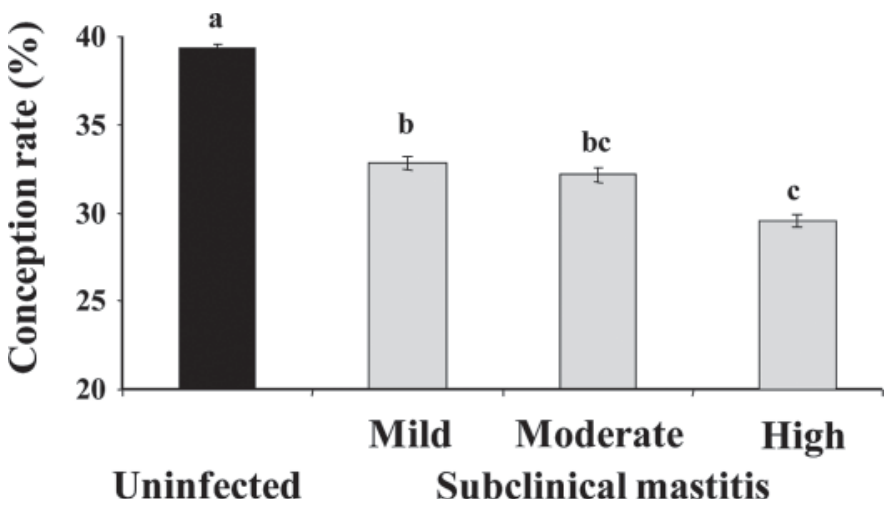

Figure 2. Effect of level of SCC in uninfected cows ( $\mathrm{n}=178,512 \mathrm{AI})$ and chronic (subclinical) mastitic cows on conception rates. Chronic cows were divided into mild $(\mathrm{n}=17,414$; $\mathrm{SCC}$ between 150,000 and $450,000$ cells $/ \mathrm{mL})$, moderate $(\mathrm{n}=12,014$; SCC between 450,000 and $10^{6}$ cells $\left./ \mathrm{mL}\right)$, and high $\left(\mathrm{n}=16,946 ;\right.$ SCC $>10^{6}$ cells $\left./ \mathrm{mL}\right)$ categories. Data are presented as mean \pm SEM. Different letters denote significant differences at $P<0.05$. 


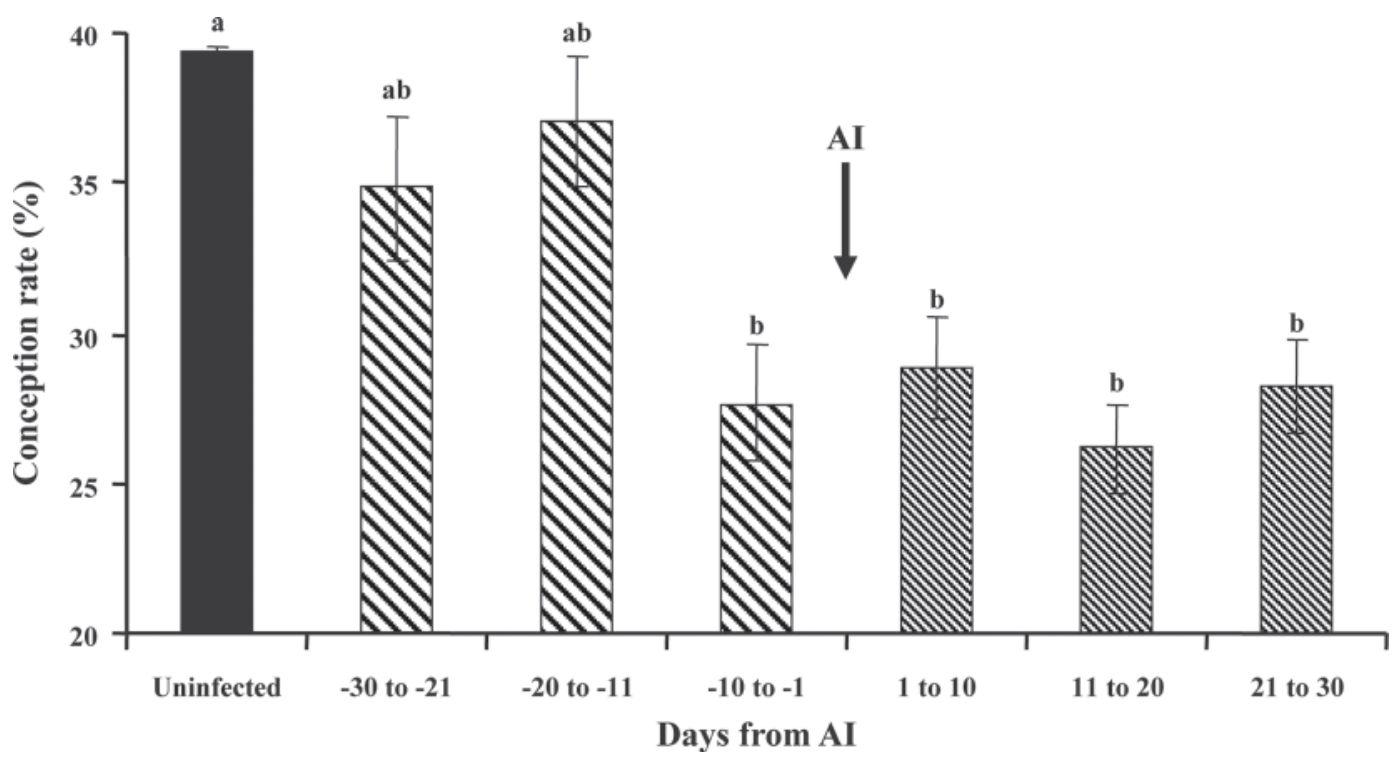

Figure 3. Effect of a single elevation of SCC above $10^{6}$ cells $/ \mathrm{mL}$ (indicative of a clinical event) occurring during 10-d periods before or after AI. Level of SCC in the 2 monthly milk test samples before and after a specific SCC elevation was $<150,000$ cells $/ \mathrm{mL}$. Data from d -1 to +1 around detected estrus and AI were excluded. For uninfected cows, 178,512 AI occurred. Number of samples in each 10-d period ranged between 405 and 899. Data are presented as mean \pm SEM. Different letters denote significant differences at $P<0.05$.

Table 3. The generalized mixed model used to estimate the effect of a single elevation, sorted by level, of SCC (most likely associated with a short-term clinical mastitis event) occurring in 10-d periods during the 30 d before or $30 \mathrm{~d}$ after AI, on probability of conception in 210,548 AI from 222 commercial dairy farms in 2002 to $2008^{1}$

\begin{tabular}{|c|c|c|c|c|}
\hline $\begin{array}{l}\text { Subgroup } \\
\text { (by SCC) }\end{array}$ & $\begin{array}{c}\text { Days } \\
\text { from AI }\end{array}$ & $\mathrm{n}$ & $\begin{array}{l}\text { LSM } \\
\text { diff. }^{2}\end{array}$ & $\mathrm{SE}$ \\
\hline Uninfected $<150,000$ & - & 178,512 & Ref. & - \\
\hline $150,000-450,000$ & $\begin{array}{c}-30 \text { to }-21 \\
-20 \text { to }-11 \\
-10 \text { to }-1 \\
1 \text { to } 10 \\
11 \text { to } 20 \\
21 \text { to } 30\end{array}$ & $\begin{array}{l}4,232 \\
4,812 \\
4,215 \\
4,269 \\
3,584 \\
2,854\end{array}$ & $\begin{array}{l}-0.005 \\
-0.003 \\
-0.011 \\
-0.018 \\
-0.055^{*} \\
-0.062^{*}\end{array}$ & $\begin{array}{l}0.010 \\
0.011 \\
0.012 \\
0.010 \\
0.009 \\
0.011\end{array}$ \\
\hline $450,000-10^{6}$ & $\begin{array}{r}-30 \text { to }-21 \\
-20 \text { to }-11 \\
-10 \text { to }-1 \\
1 \text { to } 10 \\
11 \text { to } 20 \\
21 \text { to } 30\end{array}$ & $\begin{array}{l}759 \\
922 \\
799 \\
638 \\
630 \\
509\end{array}$ & $\begin{array}{l}-0.026 \\
-0.064^{*} \\
-0.053^{*} \\
-0.027 \\
-0.057^{*} \\
-0.051^{*}\end{array}$ & $\begin{array}{l}0.025 \\
0.027 \\
0.028 \\
0.027 \\
0.025 \\
0.026\end{array}$ \\
\hline$>10^{6}$ & $\begin{array}{r}-30 \text { to }-21 \\
-20 \text { to }-11 \\
-10 \text { to }-1 \\
1 \text { to } 10 \\
11 \text { to } 20 \\
21 \text { to } 30\end{array}$ & $\begin{array}{l}783 \\
899 \\
705 \\
535 \\
486 \\
405\end{array}$ & $\begin{array}{l}-0.046 \\
-0.025 \\
-0.087^{*} \\
-0.087^{*} \\
-0.082^{*} \\
-0.082^{*}\end{array}$ & $\begin{array}{l}0.029 \\
0.034 \\
0.034 \\
0.030 \\
0.028 \\
0.029\end{array}$ \\
\hline
\end{tabular}

${ }^{1}$ Somatic cell count values in the 2 monthly milk test samples before and after a specific SCC elevation were $<150,000$ cells $/ \mathrm{mL}$. Data from d -1 to +1 around detected estrus and AI were excluded. Number of AI, variable least squares means differences, SE, and $P$-values are presented for each variable. Health problems other than mastitis, parity, season, and year of data collection significantly affected probability of conception in this data subset as in the full data set (Table 1) and are not presented here.

${ }^{2}$ The values in the LSM column are deviations from the Reference levels; reference level of the variable is 0.0 , corresponding to conception rate of 0.365 .

*A level within a variable was considered significant at $P<0.05$ if confidence range of the specific level did not overlap with the corresponding range of the reference. 
chronic, likely subclinical mastitic cows, that exhibited SCC elevation of $<10^{6}$ cell $/ \mathrm{mL}$ (mild and moderate subgroups) compared with controls. Mild and even moderate subclinical mastitis is sometimes underestimated by commercial farms as a disease causing fertility failure. Moreover, the decrease in probability of conception among the chronic cows with mild (lowest) SCC elevation was almost identical to that of the moderate subgroup. This finding is important because mild SCC elevation is often associated with CNS-induced, long-term, chronic IMI (Chaffer et al., 1999; Djabri et al., 2002). This group of bacteria is important because a large proportion of subclinical IMI is induced by CNS (Schrick et al., 2001; Taponen et al., 2006).

Large variability exists among studies examining SCC data as a criterion for subclinical mastitis-induced low fertility. Sorting of the chronic, subclinical group into mild, moderate, and high SCC levels sheds more light on this issue. For instance, a single threshold of SCC linear score at $>4.5(\sim 300,000$ cells $/ \mathrm{mL})$ before or after AI for subclinical mastitis, associated with low conception, reflected high variability in SCC elevation among individual infected cows (Pinedo et al., 2009). Indeed, in the current study, high elevation of SCC $\left(>10^{6}\right.$ cells $/$ $\mathrm{mL}$ ) before and after AI further lowered the probability of conception to a level below that of mild and moderate subclinical subgroups. Another study (Konig et al., 2006) detected a low pregnancy rate in cows exhibiting chronic elevation of SCC $>400,000$ cells $/ \mathrm{mL}$, but not (in contrast to the finding in the current study) in cows with mild elevation of 150,000 to 400,000 cells $/ \mathrm{mL}$; the reason for the differences between the studies is unclear. Finally, studies based on SCC analyses (Konig et al., 2006; Pinedo et al., 2009) showed a negative effect of chronic elevation of SCC (likely subclinical mastitis) after AI on conception, whereas Schrick et al. (2001), who sorted infected cows by bacteriological data, showed an increase in days open and services per conception only for clinical, not subclinical, IMI after AI. In this respect, SCC is only an inflammation response that can vary among bacteria and among individual animals. Moreover, the terms clinical and subclinical IMI do not reflect a clear dichotomy; for instance, animals with SCC $>10^{6}$ cells $/ \mathrm{mL}$ could potentially not show any clinical symptoms. Nevertheless, it is generally accepted that chronic inflammation is associated with cows exhibiting long-term elevation of SCC.

Before AI, a single elevation in SCC, typical of clinical IMI events, lowered the probability of conception if it occurred in the first $10 \mathrm{~d}$ before insemination, but not on earlier days, supporting Hertl et al. (2010) who found that clinical mastitis events were further divided by bacteriological data. This might explain the equivocal results of the effect of clinical mastitis occurring before AI on reproduction found in other studies: some have shown depression of reproductive performance (Santos et al., 2004), whereas others have shown a small effect on nonreturn rate (Loeffler et al., 1999). This finding is in agreement with our previous studies showing that clinical mastitis events occurring 20 to 40 $\mathrm{d}$ before AI barely induce delayed ovulation syndrome (Lavon et al., 2010), or disruption of steroidogenesis in the preovulatory follicle (Lavon et al., 2011), in contrast to the significant disrupting effects of subclinical mastitis on follicular functions.

After AI, a single elevation in SCC, typical for clinical IMI events, had a more prolonged dampening effect on the probability of conception. Similar negative effects on probability of conception due to clinical events, defined here by elevated SCC (between $\mathrm{d}+1$ and +30 ) and in Hertl et al. (2010) by clinical mastitis cases (d 0 to 35), were documented. Our findings support studies that have examined clinical cases of mastitis and report a decrease in conception of cows infected after AI (Loeffler et al., 1999; Santos et al., 2004). Taken together, the results of the current study indicate that SCC elevation before or after AI might predict depressed conception. Analysis of SCC does not require special knowledge and can be performed by new on-farm technologies. For instance, probability of depressed conception following acute clinical mastitis occurring within a 10-d period before manifestation of estrus might encourage farmers to delay AI.

The mechanism by which IMI affects CR is beyond the scope of this study. Briefly, IMI-induced release of cytokines, interleukins, and $\mathrm{PGF}_{2 \alpha}$ (Hockett et al., 2000; Bannerman et al., 2004) could be involved in lowering fertility. Before AI, IMI could disrupt LH secretion and follicular steroidogenesis, delay or block preovulatory LH surge, and disrupt ovulation (Suzuki et al., 2001; Lavon et al., 2010, 2011). Around AI, it may affect oocyte maturation and fertilization (Soto et al., 2003). After AI, mastitis may interfere with corpus luteum formation and regression, progesterone secretion, endometrial functions, and embryonic development (Gilbert et al., 1990; Mann and Lamming, 2001; Spencer et al., 2004). The exact mechanism(s) that account for IMI-induced suppression of fertility have yet to be resolved.

In conclusion, mastitis is associated with a significant reduction in probability of conception. The degree of the reduction of $\mathrm{CR}$ is related to mastitis type [short (clinical) or chronic (subclinical)], to the level of SCC elevation in response to the different bacteria, and to its exact timing of elevation relative to AI. 


\section{REFERENCES}

Aarestrup, F. M., H. D. Larsen, and N. E. Jensen. 1999. Characterization of Staphylococcus simulans strains isolated from cases of bovine mastitis. Vet. Microbiol. 66:165-170.

Bannerman, D. D., M. J. Paape, J. W. Lee, X. Zhao, J. C. Hope, and P. Rainard. 2004. Escherichia coli and Staphylococcus aureus elicit differential innate immune responses following intramammary infection. Clin. Diagn. Lab. Immunol. 11:463-472.

Chaffer, M., G. Leitner, M. Winkler, A. Glickman, O. Krifucks, E. Ezra, and A. Saran. 1999. Coagulase-negative staphylococci and mammary gland infections in cows. Zentralbl. Veterinarmed. B 46:707-712.

Djabri, B., N. Bareille, F. Beaudeau, and H. Seegers. 2002. Quarter milk somatic cell count in infected dairy cows: A meta-analysis. Vet. Res. 33:335-357.

Gilbert, R. O., W. T. K. Bosu, and A. T. Peter. 1990. The effect of Escherichia coli endotoxin on luteal function in Holstein heifers. Theriogenology 33:645-651.

Halasa, T., K. Huijps, O. Osteras, and H. Hogeveen. 2007. Economic effects of bovine mastitis and mastitis management: A review. Vet. Q. 29:18-31.

Hertl, J. A., Y. T. Gröhn, J. D. Leach, D. Bar, G. J. Bennett, R. N. González, B. J. Rauch, F. L. Welcome, L. W. Tauer, and Y. H. Schukken. 2010. Effects of clinical mastitis caused by grampositive and gram-negative bacteria and other organisms on the probability of conception in New York State Holstein dairy cows. J. Dairy Sci. 93:1551-1560.

Hockett, M. E., F. M. Hopkins, M. J. Lewis, A. M. Saxton, H. H. Dowlen, S. P. Oliver, and F. N. Schrick. 2000. Endocrine profiles of dairy cows following experimentally induced clinical mastitis during early lactation. Anim. Reprod. Sci. 58:241-251.

Hunter, R. H. F. 1994. Causes for failure of fertilization in domestic species. Pages 1-22 in Embryonic Mortality in Domestic Species. M. T. Zavy and R. D. Geisert, ed. CRC Press, Boca Raton, FL.

Konig, S., G. Hubner, R. Sharifi, E. Bohlsen, J. Detterer, H. Simianer, and W. Holtz. 2006. Relation between the somatic cell count and the success of first insemination in East Frisian dairy herds on the basis of logistic models analysis. Zuchtungskunde 78:90-101.

Lavon, Y., G. Leitner, E. Klipper, U. Moallem, R. Meidan, and D. Wolfenson. 2011. Subclinical, chronic intramammary infection lowers steroid concentrations and gene expression in bovine preovulatory follicles. Domest. Anim. Endocrinol. 40:98-109.

Lavon, Y., G. Leitner, H. Voet, and D. Wolfenson. 2010. Naturally occurring mastitis effects on timing of ovulation, steroid and gonadotrophic hormone concentrations, and follicular and luteal growth in cows. J. Dairy Sci. 93:911-921.
Loeffler, S. H., M. J. de Vries, and Y. H. Schukken. 1999. The effects of time of disease occurrence, milk yield, and body condition on fertility of dairy cows. J. Dairy Sci. 82:2589-2604.

Mann, G. E., and G. E. Lamming. 2001. Relationship between maternal endocrine environment, early embryo development and inhibition of the luteolytic mechanism in cows. Reproduction 121:175-180.

Miller, R. H., J. S. Clay, and H. D. Norman. 2001. Relationship of somatic cell score with fertility measures. J. Dairy Sci. 84:25432548 .

Parker, K. I., C. Compton, F. M. Anniss, A. Weir, C. Heuer, and S. McDougall. 2007. Subclinical and clinical mastitis in heifers following the use of a teat sealant precalving. J. Dairy Sci. 90:207-218.

Pinedo, P. J., P. Melendez, J. A. Villagomez-Cortes, and C. A. Risco. 2009. Effect of high somatic cell counts on reproductive performance of Chilean dairy cattle. J. Dairy Sci. 92:1575-1580.

Santos, J. E., R. L. Cerri, M. A. Ballou, G. E. Higginbotham, and J. H. Kirk. 2004. Effect of timing of first clinical mastitis occurrence on lactational and reproductive performance of Holstein dairy cows. Anim. Reprod. Sci. 80:31-45.

Schrick, F. N., M. E. Hockett, A. M. Saxton, M. J. Lewis, H. H. Dowlen, and S. P. Oliver. 2001. Influence of subclinical mastitis during early lactation on reproductive parameters. J. Dairy Sci. 84:1407-1412.

Schukken, Y. H., D. J. Wilson, F. Welcome, L. Garrison-Tikofsky, and R. N. Gonzalez. 2003. Monitoring udder health and milk quality using somatic cell counts. Vet. Res. 34:579-596.

Smith, K. L. 1995. Standards for somatic cells in milk: Physiological and regulatory. IDF Mastitis Newslett. 144:7-9.

Soto, P., R. P. Natzke, and P. J. Hansen. 2003. Identification of possible mediators of embryonic mortality caused by mastitis: Actions of lipopolysaccharide, prostaglandin F2 $\alpha$, and the nitric oxide generator, sodium nitroprusside dihydrate, on oocyte maturation and embryonic development in cattle. Am. J. Reprod. Immunol. 50:263-272.

Spencer, T. E., G. A. Johnson, R. C. Burghardt, and F. W. Bazer. 2004. Progesterone and placental hormone actions on the uterus: Insights from domestic animals. Biol. Reprod. 71:2-10.

Suzuki, C., K. Yoshioka, S. Iwamura, and H. Hirose. 2001. Endotoxin induces delayed ovulation following endocrine aberration during the proestrous phase in Holstein heifers. Domest. Anim. Endocrinol. 20:267-278.

Taponen, S., H. Simojoki, M. Haveri, H. D. Larsen, and S. Pyorala. 2006. Clinical characteristics and persistence of bovine mastitis caused by different species of coagulase-negative staphylococci identified with API or AFLP. Vet. Microbiol. 115:199-207. 